JURNAL PARIS LANGKIS

Jurnal Pendidikan Pancasila dan Kewarganegaraan !

Vol.2 Nomor 1, Agustus 2021

E-ISSN: 2723-7001

https://e-journal.upr.ac.id/index.php/parislangkis

\title{
MELESTARIKAN BUDAYA DI TENGAH PANDEMI (Studi Kasus Rasulan di Gunungkidul)
}

\author{
Wulan Septiyani ${ }^{1}$, Alvin Noor Fitrian ${ }^{2}$ \\ ${ }^{1}$ Program Studi Akuntansi, Fakultas Ekonomi dan Bisnis, Universitas Pembangunan Nasional \\ Veteran Yogyakarta \\ ${ }^{2}$ Program Studi Teknik Industri, Fakultas Teknik Industri, Universitas Pembangunan Nasional \\ Veteran Yogyakarta \\ Email: septiyaniwulann@gmail.com ${ }^{1}$, alvinnoorf@gmail.com ${ }^{2}$
}

\begin{abstract}
Abstrak:
The United Nations Educational, Scientific and Cultural Organization menilai bahwa Indonesia adalah negara super power dalam hal kebudayaan. Menurut data Kementerian Pendidikan dan Kebudayaan 2020, Indonesia memiliki 10.224 warisan budaya tak benda yang salah satu diantaranya adalah Rasulan. Rasulan merupakan budaya masyarakat Yogyakarta khususnya di Kabupaten Gunungkidul. Rasulan diperingati setiap tahun ketika musim panen sebagai ungkapan rasa syukur kepada Sang Pencipta. Namun di tahun ini masyarakat sedang dilanda Coronavirus Disease 2019 yang merubah berbagai tatanan kehidupan di dunia seperti kesehatan, ekonomi, dan sosial budaya. Pemerintah mengeluarkan kebijakan Pembatasan Sosial Berskala Besar, karantina diberbagai wilayah, dan beberapa hal lain yang membatasi pergerakan masyarakat. Pandemi ini dapat menjadi salah satu penghambat pelestarian budaya lokal seperti Rasulan. Perubahan pola hidup masyarakat akibat pandemi juga akan menimbulkan budaya baru yang cenderung akan melupakan budaya lokal. Penelitian ini menggunakan pendekatan kualitatif dengan teknik studi pustaka dalam mengumpulkan data. Selain sebagai ungkapan rasa syukur Rasulan tahun ini dijadikan sebagai momentum masyarakat untuk berdoa bersama agar terhindar dari berbagai penyakit dan malapetaka. Strategi masyarakat untuk melestarikan budaya Rasulan di tengah pandemi dilakukan dengan prosesi yang lebih sederhana, tetap memperhatikan protokol kesehatan, dan hanya dihadiri oleh tokoh tetua masyarakat sekitar seperti kepala desa, sesepuh desa, tokoh keagamaan, dan kepala dusun.
\end{abstract}

Kata Kunci: Rasulan, Pandemi, Budaya

\section{Abstract:}

\section{Paris Langkis}

Vol.2 Nomor 1, Agustus 2021 
The United Nations Educational, Scientific and Cultural Organization considers that Indonesia is a super power country in terms of culture. According to data from the Ministry of Education and Culture 2020, Indonesia has 10,224 intangible cultural heritages, one of which is Rasulan. Rasulan is the culture of the people of Yogyakarta, especially in Gunungkidul Regency. The apostles are commemorated every year during the harvest season as an expression of gratitude to the Creator. However, this year the community is being hit by Coronavirus Disease 2019 which has changed various ways of life in the world such as health, economy and socio-culture. The government issued a policy of large-scale social restrictions, quarantine in various areas, and several other things that limit the movement of people. This pandemic can be one of the obstacles to the preservation of local cultures such as Rasulan. Changes in people's lifestyles due to the pandemic will also create a new culture that tends to forget local culture. This study uses a qualitative approach with literature study techniques in collecting data. Apart from being an expression of gratitude, the Apostle this year is used as a momentum for the community to pray together to avoid various diseases and calamities. The community's strategy to preserve the Rasulan culture in the midst of a pandemic was carried out with a simpler procession, still paying attention to health protocols, and attended only by local community leaders such as village heads, village elders, religious leaders, and hamlet heads.

Keywords: Rasulan, Pandemic, Culture

\section{A. PENDAHULUAN}

Indonesia merupakan negara kepulauan terbesar di dunia yang mempunyai lebih dari 17.000 pulau dengan sekitar 7000 pulau yang berpenghuni (Ditjenbinaadwil, 2020). Masyarakat Indonesia terdiri dari sekitar 300 suku seperti suku Jawa, Batak, Sunda, Cina, Dayak, dan Papua. Banyaknya suku menciptakan budaya yang berbeda di setiap daerah. Tak heran jika Indonesia mendapat julukan negara Multi-Cultural (Ahmad \& Sigarete, 2018). Perbedaan inilah yang kemudian menjadi ciri khas masing-masing daerah di Indonesia.

Budaya daerah merupakan pembentuk jati diri bangsa. Budaya daerah erat kaitannya dengan sejarah, adat istiadat, dan budaya tradisional. Jenis budaya tradisional seperti upacara adat saat ini masih banyak dipertahankan dan dilestarikan oleh sebagian besar masyarakat. Bangsa Indonesia, khususnya suku Jawa memiliki sifat seremonial (Mulder, 1992). Tak heran jika sebagian besar masyarakat suku Jawa akrab dengan yang namanya upacara adat. Selain sebagai bentuk penghormatan kepada leluhur, upacara adat juga menjadi ajang wisata budaya bagi wisatawan domestik dan mancanegara. Indonesia hingga saat ini mempunyai 10.224 warisan budaya takbenda yang dicatat oleh Kementerian Pendidikan dan Kebudayaan (Kemendikbud, 2020a). Rasulan menjadi salah satu bagian dari warisan budaya Indonesia yang dicatat sejak tahun 2012. Rasulan merupakan upacara adat yang terkenal di Gunungkidul yang dilaksanakan untuk merayakan hasil panen masyarakat. Rasulan ini dimaknai sebagai hari raya ketiga masyarakat Gunungkidul selain Idul Fitri dan Idul Adha (Suharjo, 2019). Rasulan sudah ada sejak dulu dari zaman kuno ketika masyarakat setempat merayakan pesta sebagai ungkapan rasa terima kasih kepada Tuhan Yang Maha Kuasa (Bagus, 2017). Budaya Rasulan dilaksanakan melalui beberapa rangkaian kegiatan seperti upacara keagamaan,

Paris Langkis

Vol.2 Nomor 1, Agustus 2021 
parade budaya, pagelayaran wayang kulit, pertandingan olahraga, pertunjukan tradisional sampai dengan datang ke rumah kerabat untuk menikmati hidangan spesial.

Pada awal tahun 2020 beberapa negara di dunia sedang digemparkan oleh kedatangan Coronavirus Disease 2019 (Covid-19) termasuk Indonesia. Covid-19 pertama kali ditemukan di Indonesia pada tanggal 2 Maret 2020 (Moedjiono, 2020). Menurut World Health Organization (WHO) virus ini dapat menular melalui udara, droplet, permukaan yang terkontaminasi dan limbah manusia. Covid-19 merambah hampir disemua sektor kehidupan seperti ekonomi, kesehatan, transportasi maupun sosial budaya. Pelaksanaan kegiatan tertentu harus dibatalkan untuk mencegah terjadinya penularan Covid-19. Hal ini juga berdampak pada pelaksanaan Rasulan yang tidak mungkin dilakukan seperti biasanya karena melibatkan banyak orang. Masyarakat dibingungkan dengan keadaan dimana setiap orang harus menerapkan protokol kesehatan seperti sosial distancing, memakai masker dan anjuran untuk tetap tinggal di rumah. Terhambatnya pelaksanaan budaya turun temurun yang sudah menjadi ciri khas tersendiri bagi masing-masing daerah dapat menjadi ancaman kurangnya pelestarian nilai luhur budaya tersebut. Apabila hal ini terus terjadi masyarakat lama kelamaan akan lupa dan meninggalkan budaya lokal dan budaya tradisional. Rasulan sendiri diyakini masyarakat sudah ada sejak ratusan tahun yang lalu. Seiring berjalannya waktu, Rasulan mengalami beberapa adaptasi (Bagus, 2017). Perubahan ini didasarkan pada generasi muda yang ingin mengintegrasikan budaya tradisional dengan budaya modern atau menyesuaikan zaman (Berelson, 1962).

Pandemi menyebabkan beberapa budaya mengalami penyesuaian (Menrisal et al., 2020). Namun hal ini bisa memungkinkan terjadinya perubahan makna dan nilai luhur dari budaya terutama budaya tradisional yang sudah menjadi adat istiadat daerah. Sedangkan sampai saat ini belum ada pihak yang mampu memastikan kapan pandemi ini akan berakhir. Hal ini tentunya akan menjadi tantangan bagi masyarakat khususnya dalam melestarikan budaya daerah maupun tradisi yang sudah turun temurun rutin dilaksanakan (Novialayu, 2020). Berdasarkan permasalahan di atas peneliti tertarik untuk mengambil judul penelitian "Melestarikan Budaya di Tengah Pandemi (Studi Kasus Rasulan Gunungkidul)”.

\section{B. KAJIAN TEORI}

Kebudayaan adalah keseluruhan sistem gagasan, tindakan dan hasil karya manusia dalam rangka kehidupan bermasyarakat yang dijadikan milik manusia dengan belajar (Koentjaraningrat, 1983). Budaya diciptakan oleh kreativitas sekelompok orang tertentu yang menghasilkan warisan budaya (Gnoth \& Zins, 2013). Budaya dipandang sebagai keseluruhan cara hidup dari kelompok sosial tertentu dengan sistem penandaan yang berbeda, melibatkan segala bentuk kegiatan sosial dan kesenian atau aktivitas intelektual (Holden, 2004). Pengertian kebudayaan secara umum juga dijelaskan oleh Van Peur-sen, dalam bukunya Cultuur in Stroomversnelling_Een Geghel Bewekarte auitgave van Strategie van de Cultuur yang menjelaskan kebudayaan meliputi segala macam perbuatan manusia seperti cara menghayati kelahiran, kematian, dan memperingati suatu peristiwa dengan membuat upacara, mengenai seksualitas, mengolah makanan, sopan santun ketika makan, pertanian, perburuan, membuat peralatan, bala pecah, pakaian, cara menghias

\section{Paris Langkis}

Vol.2 Nomor 1, Agustus 2021 
rumah dan badan. Semua itu termasuk dalam kebudayaan, seperti juga kesenian, ilmu pengetahuan dan agama (Peursen, 1975). Hakikat kebudayaan memiliki beberapa sifat antara lain (Soekanto \& Sulistyowati, 2013):

1. Kebudayaan diwujudkan dan disalurkan melalui perilaku manusia.

2. Kebudayaan lahir mendahului lahirnya manusia dan tidak akan pernah habis hingga hilangnya manusia.

3. Manusia memerlukan kebudayaan dan mewujudkannya melalui sikap.

4. Kebudayaan mencakup aturan-aturan yang berisikan kewajiban tertentu.

5. Tindakan yang diterima dan ditolak, tindakan yang dilarang, dan tindakan yang diizinkan.

\section{METODE PENELITIAN}

Penelitian ini menggunakan pendekatan kualitatif dengan teknik studi pustaka. Penelitian dilakukan dengan metode analisis deskriptif yang menjelaskan data secara mendalam. Data yang digunakan dalam penelitian adalah data sekunder yang didapat dari jurnal penelitian, artikel, berita, maupun dokumentasi lain dari berbagai sumber. Penelitian ini dilakukan di Kabupaten Gunungkidul dengan mengambil beberapa sampel dari beberapa daerah yang mengadakan Rasulan di tengah pandemi.

\section{HASIL DAN PEMBAHASAN}

Pada Bulan Maret tahun 2020 sebagian besar institusi budaya di seluruh dunia ditutup karena pandemi Covid-19. Kondisi tersebut tidak memungkinkan bagi instansi budaya untuk menyelenggarakan festival, pameran, pertunjukkan dan acara seni lainnya secara langsung. Pihak pemerintah membatasi aktivitas publik dengan anjuran untuk tetap tinggal dirumah, sosial distancing, dan larangan melakukan perjalanan. Perkembangan jumlah kasus terkonfirmasi positif Covid-19 per tanggal 22 Januari 2021 sebanyak 965.283 orang dengan 27.453 kematian (Kemenkes, 2020). Sementara masyarakat daerah mengalami kebingungan terkait pelaksanaan tradisi atau upacara adat yang tetap harus dilaksanakan. Pandemi ini mengakibatkan beberapa upacara adat di berbagai daerah terpaksa ditunda atau bahkan dibatalkan.

Upacara tradisional adalah rangkaian kegiatan atau tindakan manusia berdasarkan adat yang berlaku dalam masyarakat tertentu serta berkaitan dengan kepercayaan. Upacara tradisional atau biasa disebut upacara adat juga merupakan suatu ekspresi keagamaan yang dilaksanakan oleh kelompok masyarakat setempat dan sudah berlangsung sejak lama atau turun-temurun yang berwujud sebagai suatu aturan atau sistem perbuatan. Upacara tradisional menjadi salah satu bentuk tradisi yang dapat dipakai sebagai sarana pelestarian kebudayaan dan menjadi manifestasi kehidupan setiap orang dan kelompok orang (Cathrin, 2017). Upacara adat ini diwariskan secara turun temurun dari generasi ke generasi berikutnya sehingga sampai sekarang masih terasa kental dengan kemagisannya.

Salah satu upacara adat yang masih dilaksanakan sampai saat ini adalah upacara adat bersih desa atau biasa disebut Rasulan yang diselenggarakan oleh masyarakat Kabupaten Gunungkidul, Provinsi Daerah Istimewa Yogyakarta setiap tahunnya. Rasulan berasal dari kata dasar Rasul, akronim dari kata beras/padi dan masul yang berarti pulang.

Paris Langkis

Vol.2 Nomor 1, Agustus 2021 
Rasulan diartikan beras wus masul atau beras sudah dibawa pulang (panen). Rasulan atau bersih desa menjadi bagian yang tidak terpisahkan bagi masyarakat Gunungkidul. Pasalnya Rasulan ini sudah ada sejak lama, bahkan sejak agama Islam belum masuk di Gunungkidul (Brahmanto, 2014). Menurut masyarakat setempat Rasulan merupakan upacara adat Jawa atau biasa disebut slametan yang dilakukan dengan memberikan sesaji kepada danyang desa. Sesaji ini bertujuan untuk membersihkan desa dari roh jahat yang mengganggu masyarakat. Danyang dipercaya masyarakat sebagai penjaga desa.

Masyarakat Gunungkidul mayoritas bekerja sebagai petani. Hal tersebut menjadi salah satu penyebab kemunculan tradisi Rasulan di Gunungkidul. Rasulan dimaknai sebagai ungkapan rasa syukur masyarakat kepada Sang Pencipta atas hasil panen yang diterima. Bahkan hampir semua wilayah di Gunungkidul melaksanakan tradisi Rasulan, mulai dari ujung timur Kecamatan Girisubo hingga ujung barat Kecamatan Panggang (Dewanti et al., 2020). Pelaksanaan Rasulan di setiap daerah rutin selama satu tahun sekali pada waktu dan tempat tertentu yang berbeda-beda. Ciri khas Rasulan Gunungkidul ditandai dengan pelaksanaan kirab gunungan. Pelaksanaan Rasulan umumnya dilakukan selama 3 hari yaitu pada hari pertama melaksanakan tradisi bersihbersih desa, hari kedua pertunjukkan budaya, dan hari terakhir persahabatan antar tetangga (Brahmanto, 2014). Setiap daerah di Gunungkidul memiliki keunikan masingmasing dalam perayaan Rasulan. Mulai dari kegiatan bersih-bersih lingkungan, kenduri, pagelaran wayang, pertunjukan jathilan, kirab gunungan, pertandingan sepak bola, pengajian, dan pertunjukkan seni lainnya seperti kethoprak.

Pelaksanaan Rasulan melibatkan banyak pihak mulai dari anak-anak hingga sesepuh desa. Masyarakat saling bekerja sama gotong-royong berkontribusi dalam kegiatan Rasulan, namun situasi mulai berubah pada tahun 2020. Indonesia kedatangan pandemi Covid-19 yang mengharuskan masyarakat untuk tetap tinggal di rumah. Banyak kegiatan baik seni maupun budaya yang harus ditunda atau bahkan dibatalkan. Namun, berbeda dengan masyarakat Gunungkidul yang tetap harus memperjuangkan adat istiadat mereka yaitu tradisi Rasulan. Dalam situsi seperti ini tentunya masyarakat mengambil banyak pertimbangan untuk tetap melaksanakan Rasulan, mengingat kebijakan pemerintah untuk melakukan sosial distancing. Dikutip dari laman kompas.com Juli 2020, pelaksanaan Rasulan di tengah pandemi berlangsung secara sederhana dan sepi (Kompas, 2020). Pelaksanaan Rasulan tahun ini hanya dilakukan melalui ritual dan kenduri sederhana oleh sejumlah tokoh yang membawa berbagai makanan di tempat terbuka. Upacara Rasulan dilaksanakan di tempat terbuka dengan tujuan sosial distancing. Tidak ada sanak saudara yang berkunjung untuk merayakan Rasulan seperti tahun-tahun sebelumnya. Berdasarkan hasil wawancara salah satu wartawan Kompas kepada seorang warga Kecamatan Playen, mengatakan bahwa biasanya upacara Rasulan digelar seperti hajatan dengan banyak makanan namun persiapan makanan tahun ini lebih sedikit, karena hanya untuk kenduri dan tidak ada saudara yang berkunjung (Kompas, 2020). Tidak ada hiburan, pertunjukkan, maupun kirab gunungan. Rasulan pada tahun ini hanya dilaksanakan dengan kenduri di masing-masing daerah. Dalam kenduri tersebut hanya dihadiri oleh Kepala Dusun, Ketua RT, tokoh agama, dan sesepuh masing-masing daerah. Perayaan Rasulan tahun ini diserahkan ke masing-masing Ketua RT di setiap daerah dengan tujuan untuk tetap mematuhi protokol kesehatan. Selain sebagai ungkapan rasa

Paris Langkis

Vol.2 Nomor 1, Agustus 2021 
syukur, Rasulan digelar dalam rangka mendoakan warga sekitar agar terhindar dari berbagai macam penyakit. Berdasarkan hasil wawancara salah satu wartawan Merdeka.com dengan Kepala Desa Kalurahan Nglindur Kecamatan Girisubo, menyebutkan bahwa tradisi Rasulan ini dilakukan sebagai upaya warga masyarakat sekitar agar tidak tertular Covid-19 (Merdeka.com, 2020).

Rasulan menjadi salah satu faktor penyebab Kota Yogyakarta disebut sebagai kota yang istimewa. Masyarakat berpendapat bahwa tradisi Rasulan harus tetap dilaksanakan meskipun dengan mengikuti protokol kesehatan (Liputan6, 2020). Hal ini dilakukan untuk tetap menjaga warisan para leluhur serta mengingat kembali nilai-nilai luhur yang diciptakan. Rasulan merupakan salah satu dari sekian banyak upacara tradisi di Gunungkidul bahkan di Yogyakarta dan sudah menjadi warisan budaya. Berdasarkan pencatatan Kementerian Pendidikan dan Kebudayaan, Rasulan sudah menjadi salah satu bagian dari warisan budaya takbenda Indonesia sejak tahun 2012. Uniknya, di tengah perkembangan zaman yang terjadi masyarakat tetap melaksanakan Rasulan secara turuntemurun dan tidak ada masyarakat yang ingin menghilangkan tradisi tersebut (Wulandari et al., 2018).

Pewarisan budaya Rasulan secara turun-temurun mempunyai peran yang sangat penting. Pewarisan ini dilakukan oleh generasi tua kepada generasi selanjutnya, sehingga sampai saat ini di era modernisasi Rasulan masih menjadi tradisi yang dijunjung oleh masyarakat Gunungkidul beserta pemerintah setempat dan menjadi agenda tahunan. Pewarisan budaya ini ditunjukkan dengan proses sosialisasi yang terjadi melalui pelaksanaan tradisi Rasulan. Sosialisasi merupakan proses penyampaian informasi kepada orang lain yang bertujuan untuk mempengaruhi orang tersebut mengikuti apa yang disosialisasikan. Peran antar keluarga tidak terlepas dari terlaksananya tradisi Rasulan hingga sampai saat ini (Wardhan et al., 2019). Setiap keluarga mensosialisasi anakanaknya sesuai dengan kebudayaan masyarakat (Dwiningrum, 2016). Tidak heran bahwa tradisi Rasulan sudah menjadi jiwa dari masyarakat Gunungkidul. Semua elemen masyarakat dari anak-anak hingga sesepuh desa turut berpartisipasi dalam tradisi ini. Sosialisasi Rasulan dilakukan oleh berbagai unsur mulai dari keluarga, masyarakat, pemerintah dan juga lembaga pendidikan. Semua pihak saling berkerja sama dalam melakukan sosialisasi ini agar semua masyarakat dapat memahami arti penting dari Rasulan. Hal ini juga memberikan tanggungjawab kepada anak-anak maupun generasi muda untuk terus melakukan Rasulan setiap tahunnya.

Apabila pandemi ini terus berlanjut dan masyarakat tidak berinisiatif untuk tetap mempertahankan tradisi ini, besar kemungkinan nilai-nilai sosialisasi tradisi Rasulan akan menghilang. Tidak hanya itu, perkembangan teknologi komunikasi dan budaya-budaya barat yang semakin menarik masyarakat untuk melupakan budaya lokal juga menjadi ancaman bagi tradisi Rasulan. Pandemi Covid-19 menyebabkan masyarakat enggan untuk bertemu orang lain karena kekhawatiran akan tertular virus yang kemudian akan menjadikan masyarakat untuk bersikap individualis. Namun, masyarakat juga harus mempertimbangkan nilai-nilai luhur Rasulan yang harus tetap dijaga dan dilestarikan. Merenungi simbol-simbol yang ada dalam Rasulan merupakan salah satu cara untuk mengingatkan masyarakat terkait pentingnya melestarikan tradisi ini.

Paris Langkis

Vol.2 Nomor 1, Agustus 2021 
Nilai-nilai budi pekerti tradisi Rasulan disampaikan melalui berbagai media. Ciri khas Rasulan adalah diadakannya kirab gunungan yang berisi hasil bumi. Gunungan tersebut berbentuk kerucut dengan runcing ke atas. Hal ini menggambarkan bahwa sebagai ciptaan Tuhan yang tercipta dengan berbagai perbedaan, harus berpandangan secara vertikal yang berarti selalu mengingat dan bersyukur kepada Tuhan (Wulandari et al., 2018). Gunungan ini berisi berbagai macam hasil panen mulai dari terong, tomat, cabai, kacang panjang dan lain-lain yang menandakan meskipun manusia diciptakan dengan berbagai karakter, agama, dan bahasa harus bersatu dan bekerja sama untuk senantiasa bersyukur kepada Tuhan. Nilai toleransi yang ada dalam Rasulan yaitu sikap saling menghargai perbedaan yang ada. Hal ini diwujudkan bahwa tradisi Rasulan itu diikuti oleh semua umat beragama, tidak hanya umat muslim. Nilai keikhlasan diwujudkan masyarakat melalui waktu, tenaga, dan rezekinya untuk pelaksanaan tradisi rasulan. Masyarakat juga memberikan sumbangan yaitu iuran untuk kegiatan rasulan dan menyediakan makanan. Nilai kepedulian diwujudkan masyarakat melalui kegiatan makan bersama dengan mengundang sanak saudara dari daerah lain. Banyaknya nilai-nilai luhur yang terkandung dalam kegiatan Rasulan membuat masyarakat enggan untuk meninggalkan Rasulan begitu saja. Nilai-nilai budi pekerti yang dihasilkan dari tradisi Rasulan harus terus dipupuk dan dikembangkan oleh masyarakat. Seiring dengan perkembangan zaman pelaksanaan Rasulan juga mengalami perubahan, namun tidak menghilangkan tradisi yang ada. Penambahan adanya pertunjukkan kesenian merupakan salah satu contoh perkembangan Rasulan dalam menyesuaikan zaman.

Pandemi Covid-19 memunculkan budaya baru dalam masyarakat seperti memakai masker, mencuci tangan dan menjaga jarak. Masyarakat terpaksa mengubah kebiasaan sosial, pemberlakukan social distancing dan lockdown telah membuat digital menjadi ruang publik yang mengaitkan individu dan masyarakat menjadi hal yang penting. Jumlah pengguna internet di Indonesia hingga kuartal II/2020 mencapai 196,7 juta atau 73,7\% dari populasi penduduk Indonesia. Jumlah ini bertambah sekitar 25,5 juta pengguna dibandingan tahun lalu sebelum pandemi. Hal ini bisa menjadi salah satu strategi masyarakat untuk melestarikan sekaligus mempromosikan budaya Rasulan. Dengan mengunggah video maupun gambar terkait pelaksanaan Rasulan bisa menjadikan pengingat bagi masyarakat untuk tetap menjaga tradisi tersebut. Penggunaan platform digital seperti website, youtube, dan media sosial bisa menjadi peluang bagi masyarakat Gunungkidul untuk memperkenalkan tradisi Rasulan. Tidak hanya itu, dengan adanya platform digital ini dapat membantu generasi selanjutnya dalam mengingat dan mengetahui pelaksanaan Rasulan dimasa lalu. Hal ini juga mengenalkan generasi muda terhadap nilai-nilai luhur dan mengajarkan untuk cinta budaya. Selain menekan penyebaran Covid-19 pelaksanaan Rasulan secara virtual dapat menjadi salah satu peluang masyarakat dalam melestarikan sekaligus memajukan budaya Gunungkidul. Pelaksanaan Rasulan secara virtual ini bisa disaksikan oleh seluruh masyarakat baik dalam maupun luar negeri. Hal ini juga menjadi momentum untuk memperkenalkan budaya Rasulan Gunungkidul ke seluruh dunia.

Apabila pandemi Covid-19 akan berlangsung dalam periode yang lama, masyarakat perlu mempersiapkan berbagai inovasi untuk tetap melaksanakan tradisi Rasulan setiap tahunnya. Lama-kelamaan masyarakat juga akan mulai terbiasa dengan

Paris Langkis

Vol.2 Nomor 1, Agustus 2021 
kebijakan pemerintah terkait sosial distancing. Hal ini tidak akan menjadi penghambat masyarakat dalam melestarikan Rasulan. Pelaksanaan Rasulan dapat digelar dengan tetap memperhatikan protokol kesehatan sesuai anjuran pemerintah. Dikutip melalui laman kebudayaan.kemendikbud.go.id Presiden Joko Widodo dalam membuka Pekan Kebudayaan Nasional Tahun 2020, berpesan kepada semua insan seni dan budaya agar pandemi Covid-19 tidak menjadi penghalang untuk tetap berkreasi. Beliau mengatakan bahwa di saat seperti inilah seluruh pihak tidak boleh menyerah dengan kesulitan dengan tetap berkreasi dan bergerak maju membangun memori masa depan yang lebih baik (Kemendikbud, 2020b). Pelaksanaan Pekan Kebudayaan Nasional tersebut menjadi bukti bahwa para budayawan dan para pekerja seni Tanah Air tidak mau tunduk dan menyerah karena pandemi Covid-19. Hal tersebut tidak dijadikan tantangan melainkan peluang untuk tetap mempertahankan dan menciptakan kreasi budaya baru demi membangun peradaban Indonesia maju.

Melestarikan kebudayaan lokal merupakan kewajiban dari para generasi muda. Dengan melestarikan kebudayaan lokal, secara tidak langsung nilai-nilai luhur yang terkandung di dalamnya ikut terjaga dan tetap berkembang di masyarakat. Kebudayaan lokal memiliki nilai-nilai yang sejalan dengan kehidupan. Sebagai contoh Rasulan selalu melibatkan generasi muda dalam pelaksanaannya. Pemuda lokal (karang taruna) selalu ikut andil dalam setiap pelaksanaan kegiatan, mulai dari pembentukan panitia sampai dengan pelaksanaan upacara Rasulan itu sendiri. Dalam pelaksanaannya terdapat nilainilai yang sejalan dengan kehidupan seperti gotong royong, bekerja sama, toleransi, mendahulukan kepentingan kelompok, berfikir kritis dan lain-lain. Peran generasi muda merupakan hal yang penting dalam upaya pelestarian Rasulan di tengah pandemi ini. Dengan generasi muda yang tanggap, aktif dan kreatif dapat membantu masyarakat dalam menjaga dan meletarikan tradisi dan adat istiadat. Generasi muda yang paham akan sejarah, adat istiadat, dan tradisi daerah merupakan aset dari kebudayaan Indonesia. Dengan perkembangan teknologi yang kian pesat, diharapkan generasi muda dapat memanfaatkannya untuk melestarikan kebudayaan daerah. Upaya pelestarian budaya dapat dilakukan dengan perluasan literasi kebudayaan melalui website atau video yang diunggah melaui platform digital. Pengadaan kegiatan seperti webinar juga dapat menambah pengetahuan masyarakat mengenai Rasulan dan memahami nilai-nilai luhur yang pada Rasulan. Hal ini dilakukan untuk mencegah terjadinya krisis pengetahuan tentang kebudayaan di masa yang akan datang.

Kontribusi pemerintah baik melalui pemerintah provinsi dan pemerintah kabupaten sangat diperlukan untuk dapat membantu pelestarian budaya Rasulan di tengah pandemi. Kontribusi ini diperlukan agar kebudayaan daerah tidak luntur dari masyarakat. Peran pemerintah dalam hal ini dapat dilakukan dengan cara mempublikasikan kegiatan Rasulan dengan memanfaatkan media cetak maupun elektronik atau bahkan publikasi dari mulut ke mulut. Pemerintah juga dapat mengenalkan pentingnya nilai-nilai luhur yang ada pada Rasulan dengan menjadi pembicara dalam kegiatan seminar online. Dengan berbagai upaya baik dari masyarakat, generasi muda dan pemerintah diharapkan tradisi Rasulan di Gunungkidul dapat terus dilestarikan dan dikenal masyarakat dalam dan luar negeri.

Paris Langkis

Vol.2 Nomor 1, Agustus 2021 


\section{E. KESIMPULAN}

Rasulan adalah salah satu upacara adat yang sudah menjadi agenda tahunan masyarakat Gunungkidul. Tradisi ini dilaksanakan sebagai bentuk ungkapan rasa syukur kepada Tuhan Yang Maha Esa atas semua berkah panen yang didapatkan para petani. Pelaksanaan Rasulan di tahun 2020 mengalami berbagai hambatan dengan kedatangan pandemi Covid-19. Masyarakat Gunungkidul dibingungkan dengan adanya regulasi sosial distancing dari pemerintah. Namun, untuk tetap menjaga dan melestarikan budaya Rasulan ini, masyarakat Gunungkidul tetap melaksanakan Rasulan di tengah pandemi dengan tetap memperhatikan protokol kesehatan. Banyak hal yang dipertimbangkan untuk tetap melaksanakan Rasulan ini diantaranya adalah tetap menjaga nilai-nilai luhur seperti pentingnya sosialisasi, keikhlasan, kepedulian, toleransi, bersyukur, dan menghargai perbedaan. Rasulan sudah menjadi jiwa masyarakat Gunungkidul yang tidak dapat dipisahkan. Apabila pandemi akan terus berlanjut diperlukan inovasi dari pemerintah daerah, masyarakat dan peran generasi muda menjaga dan melestarikan tradisi Rasulan. Inovasi tersebut diantaranya dapat mengadakan kegiatan webinar terkait Rasulan dan pentingnya nilai luhur, mengadakan upacara Rasulan melalui video konference atau dengan media lain secara virtual. Pemerintah juga dapat memberikan kontribusinya melalui publikasi kegiatan Rasulan baik melalui media cetak maupun elektronik. Upaya ini dapat dilakukan dengan memanfaakan perkembangan teknologi dan informasi sebagai media pelestarian Rasulan melalui platform digital seperti website maupun sosial media. 


\section{DAFTAR PUSTAKA}

Ahmad, H., \& Sigarete, B. G. (2018). Preferensi Mahasiswa Dalam Berwisata: Studi Kasus Mahasiswa Sekolah Tinggi Pariwisata Ambarrukmo (STIPIRAM) Yogyakarta. Ejournal.Stipram.Ac.Id, Kepariwisataan: Jurnal Ilmiah, 12(1).

Bagus, C. (2017). Sosialisasi Adat Rasulan di Kalangan Anak-Anak pada Era Modernisasi di Daerah Playen, Gunungkidul. In jurnal.uns.ac.id (Vol. 6, Issue 1).

Berelson, B. (1962). The social studies and the social sciences.

Brahmanto, E. (2014). Tradisi Rasulan Menjadi Andalan Etnik Tourism Kabupaten Gunung Kidul Yogyakarta. Khasanah Ilmu, Jurnal Pariwisata Dan Budaya, V(2), 6975.

Cathrin, S. (2017). Tinjauan Filsafat Kebudayaan Terhadap Upacara Adat Bersih Desa di Desa Tawun, Kecamatan Kasreman, Kabupaten Ngawi, Jawa Timur. In journal.ugm.ac.id.

Dewanti, F. M. H., Assingkily, M. S., \& Kamala, I. (2020). Tradisi Rasulan: Nilai Pendidikan dari Kearifan Lokal Desa Selang Wonosari Gunungkidul. MIDA: Jurnal Pendidikan Dasar Islam, 3(1), 53-64.

Ditjenbinaadwil. (2020). Koordinasi Penyamaan Persepsi Jumlah Pulau di Indonesia Tahun 2020.

Dwiningrum, S. I. A. (2016). Pendidikan Sosial Budaya.

Gnoth, J., \& Zins, A. H. (2013). Developing a tourism Cultural Contact Scale Experience View project Quality stakeholder relationships for efficient retail crime prevention in New Zealand View project Developing a tourism Cultural Contact Scale. Article in Journal of Business Research. https://doi.org/10.1016/j.jbusres.2011.09.012

Holden, A. (2004). Tourism Studies and the Social Sciences.

Kemendikbud. (2020a). Pencatatan Warisan Budaya Takbenda.

Kemendikbud. (2020b). Presiden Joko Widodo Buka Pekan Kebudayaan Nasional 2020.

Kemenkes. (2020). Perkembangan JUmlah Kasus Covid-19 Terkonfirmasi.

Koentjaraningrat. (1983). Pengantar Ilmu Antropologi.

Kompas. (2020). Tradisi Rasulan di Gunungkidul, Bertahan meski Sepi karena Pandemi Halaman.

Liputan6. (2020). Menjaga Tradisi Rasulan Gunungkidul di Tengah Pandemi Covid-19.

Menrisal, Radyuli, P., Sanjaya, D., \& Zuzanti, Z. (2020). Kontribusi Lingkungan Belajar dan Sarana Prasarana Terhadap Hasil Belajar Siswa Mata Pelajaran TIK. Jurnal Paris Langkis, 1(1), 51-62.

Merdeka.com. (2020). Tetap Digelar, Begini Prosesi Tradisi Rasulan di Gunung Kidul Saat

Paris Langkis

Vol.2 Nomor 1, Agustus 2021 
Masa Pandemi.

Moedjiono, A. W. (2020). Sejarah Panjang Virus Korona. Kompas.com.

Mulder, N. (1992). Individual and Society In Java: A Cultural Analysis.

Novialayu, E. (2020). Pelaksanaan Perkawinan Menurut Adat Dayak Ngaju Di Kecamatan Timpah Kabupaten Kapuas. Jurnal Paris Langkis, 1(1), 1-14. https://ejournal.upr.ac.id/index.php/parislangkis/article/view/1665

Peursen, C. Van. (1975). Cultuur in Stroomversnelling Een Geheel Bewerkte Uitg. Van Strategie van de Cultuur.

Soekanto, S., \& Sulistyowati, B. (2013). Sosiologi Suatu Pengantar: Rajawali Pers.

Suharjo, I. (2019). Budaya Rasulan di Gunungkidul.

Wardhan, M., Rahmah, N., Ma'rufah, H., Audina, N., Nurokhim, N., \& Habibah, U. (2019). Kajian Empiris Kuliah Kerja Nyata (KKN) UIN Sunan Kalijaga terhadap Nilai Kearifan Lokal Tradisi Rasulan Gunung Kidul. Prosiding Konferensi Pengabdian Masyarakat, 1, 113-115.

Wulandari, Ervina, Nurkholidah, A. F., \& Solikhah, C. (2018). Penguatan Nilai Budi Pekerti Melalui Tradisi Rasulan Gunung Kidul. Habitus: Jurnal Pendidikan, Sosiologii Dan Antropologi, 2(1), 139-150. 